Military Technical College

Kobry El-Kobbah,

Cairo, Egypt

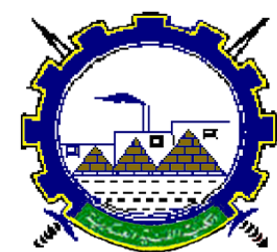

I.C.E.E.2016 $8^{\text {th }}$ International Conference

on

Chemical \& Environmental

Engineering

$19-21$ April 2016

\title{
EEA-3
}

\section{Adsorption behaviours of ammonia onto modified activated carbon derived from date pits}

\author{
Eman A. Ashour ${ }^{1}$, Maha A. Tony ${ }^{2 *}$
}

\begin{abstract}
The increase in population, urbanization and industrialization put a pressure on water resources management in Egypt. Ammonia is one of the significant sources of the water pollution from Abo Rawash in Rosetta branch of Nile River. When ammonia is present in water at high enough levels, leading to potentially death to aquatic animals. Searching for the best environmental and economical sound solution is an important point.

Activated carbon was prepared by chemical activation of low cost waste, dates stone, called activated date pits (ADP) was used to remove ammonia from water. Equilibrium adsorption isotherm of ammonia from wastewater was investigated. Different operating parameters were examined to obtain the maximum removal efficiency, such as operating temperature, mass of ADP, ammonia concentration and agitation speed. The equilibrium time was reached after 180 minutes of contact time, however, the optimum agitation speed was $500 \mathrm{rpm}$. The study of kinetic models showed the reaction follows the first order model. Moreover, equilibrium adsorption data fitted the Langmuir adsorption isotherm well with $\mathrm{R}^{2}>0.99$. The obtained results showed that the maximum adsorption capacity of ADP for the removal of ammonia was reached to $37 \%$ at $333 \mathrm{~K}$.
\end{abstract}

Keywords: Adsorption; Ammonia, Agriculture adsorbent; Date pits; Wastewater.

\footnotetext{
${ }^{1}$ Chemical Engineering Department, Faculty of Engineering, EL-Minia University, EL-Minia, Egypt

${ }^{2}$ Basic Engineering Science Department, Faculty of Engineering, Minoufiya University, Shbin El-koum, Minoufiya, Egypt

*Corresponding Author: Tel: +2048-2221549, Fax: +20482235695, Email: maha_tony1@yahoo.com
} 
Military Technical College

Kobry El-Kobbah,

Cairo, Egypt

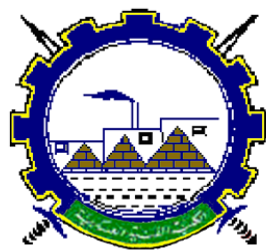

I.C.E.E.2016 $8^{\text {th }}$ International Conference

on

Chemical \& Environmental

Engineering

$19-21$ April 2016

\section{Introduction}

Egypt is facing increasing water needs, demanded by a rapidly growing population, increased urbanization, higher standards of living and an agricultural policy, which emphasizes expanded production in order to feed the growing population.

The policy of the ministry of Water Resources and Irrigation in Egypt relies on using all the available water resources in a rational way to cover the increasing water needs. The major challenge of this policy is the degradation of surface and groundwater quality by domestic and industrial pollution. A great amount of water is spilled yearly in the Mediterranean Sea to dilute the pollution in Rosetta branch which is the main water supply source for many cities in the Nile Delta as Kafr Elzayat, Menofya and Disuq. Also, preserving the aquatic life in Rosetta branch specially fish is another important issue.

At Kafr El-Zayat, Rosetta branch receives also industrial effluents from Salt and Soda companies. Rosetta branch receives also drainage water from agricultural areas fertilized by animal manure and chemicals [1].

Ammonia is a common water contaminant. Ammonia contamination has become an environmental concern worldwide because that has notable harmful effects upon the environment and human health when present in excess amounts. Thus, it is toxic to human beings and animals [2]. Ammonia is present in most waters as a result of the biological degradation of nitrogenous compounds. Common Environmental sources of ammonia pollution include industrial wastes, agricultural input and sewage effluents. Ammonia nitrogen discharges from these sites, subsequently gains entrance into water resources and causes threat to aquatic life. Other potential sources of ammonia pollution are the animal feeds, food additives, cleaning agents and from the industries manufacturing fibers, plastics, explosives, paper, and rubber; further ammonia is also a metabolic by-product of fish [1-5].

The maximum limit of ammonia set by the European Association for drinking water is approximately $0.5 \mathrm{ppm}$ and also a guide level is given as $0.05 \mathrm{ppm}$. The raw water with high ammonia concentration must therefore be treated before it reaches the consumer and also the wastewater discharge into the receiving water. Therefore the removal of ammonia from wastewaters assumes importance [6-8].

Ammonia presence even in very low concentrations causing various health disorders such as headache, insomnia, nausea, diarrhea and toxicity in the brain. Ammonia affects the aquatic life as it is a strong cell poison and damage the fish. Further, it presence in waters causes depletion of dissolved oxygen in water bodies and consequential loss of valuable aquatic species due to decrease in dissolved oxygen [1]. 
Military Technical College

Kobry El-Kobbah,

Cairo, Egypt

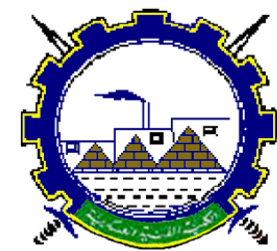

I.C.E.E.2016 $8^{\text {th }}$ International Conference

on

Chemical \& Environmental

Engineering

$19-21$ April 2016

So research efforts dealing with the processes affecting the removal of ammonia from contaminated wastewater effluents are critically needed in order to prevent further damage to surface and groundwater bodies.

Many processes have been used in the pretreatment of ammonium from wastewater, such as air stripping [9] membrane separation processes [10] chemical precipitation [11]. Activated carbon is an amorphous form of carbon that is specially treated to produce a highly developed internal pore structure and a large surface area, thus, producing reasonably cheap and excellent adsorbent [12-13]. It is used widely as adsorbent. Prameela and Ravindhranath applied plant materials derived from Tamarindus indicia for the removal ammonia in water [14]. In addition, Zendehzaban et al., (2012) used $\mathrm{TiO}_{2}$ for adsorption of ammonia [15].

For instance, using an agriculture waste as an adsorbent material is gaining too much importance. The use of date pits as a source of activated carbon is most attractive and efficient adsorbent material suitable for the removal process. For instance, Parimala et. al., (2007) investigated the removal of ammonia using low cost agricultural wastes [16]. Duck weeds [17], neem products [18] and low cost agricultural wastes [16, 19] have been explored for the removal of ammonia from polluted waters.

The use of date pits lies in the importance of environmental and economical aspects. For instance, Belhachemi and Addoun (2011) applied it for the treatment of methylene Blue wastewater [20]. Moreover, Alhamed (2006) used the activated date stones for both removal of phenols and methylene blue [21]. However, there is a lack in the literature for the application of the date pits for ammonia removal.

Trend of using economic products from agriculture waste in removing organic pollutants from water became highly accepted. So, the current study discussed the optimum experimental conditions to utilize activated carbon, produced from agriculture by-product waste which is namely date pits (ADP).

\section{Materials and Methods}

\section{Materials}

The materials used in the experimental work have been divided into: Adsorbent and Adsorbate. The adsorbent used in all experiments is Activated carbon obtained from date stone, and the Adsorbate used was the ammonium chloride solution.

\section{Activated date pits (ADP)}

The Date pits (shown in Fig. 1 and its composition is shown in Table 1) were dried at $110^{\circ} \mathrm{C}$ for $24 \mathrm{~h}$ to reduce the moisture content. The dried date stones were then crushed and sieved. Size fractions of 1-2 mm were used in this study. 
Military Technical College

Kobry El-Kobbah,

Cairo, Egypt

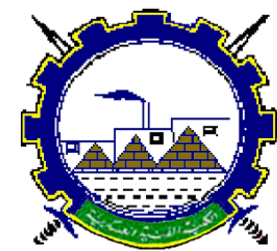

I.C.E.E.2016 $8^{\text {th }}$ International Conference

on

Chemical \& Environmental

Engineering

$19-21$ April 2016

The preparation of activated carbon was conducted in two steps: carbonization and activation. Both carbonization and activation were carried out in a stainless steel 316 reactor (length 700 $\mathrm{mm}$ and internal diameter $25 \mathrm{~mm}$ ); the reactor was admitted into a vertical tube furnace. In the activation step, the resulting char was immersed in phosphoric acid with different weight ratio [1:3 DS: $\left.\mathrm{H}_{3} \mathrm{PO}_{4},(\mathrm{~W} / \mathrm{W})\right]$ and the mixtures were kneaded with adding distilled water. The mixtures were then dried at $110^{\circ} \mathrm{C}$ for $24 \mathrm{~h}$. The impregnated sample was placed in the reactor and heated up to $500^{\circ} \mathrm{C}$ under $\mathrm{N}_{2}$ flow for $2 \mathrm{~h}$. After activation, the sample was cooled down under $\mathrm{N}_{2}$ flow, washed sequentially several times with hot distilled water until $\mathrm{pH}$ of water reached 7.0, then the sample was dried for $24 \mathrm{~h}$ and finally kept in a tightly closed bottle. The surface area of the prepared ADS is $\mathrm{S}_{\mathrm{BET}} 873 \mathrm{~m}^{2} / \mathrm{g}$.

Table 1 Approximate composition of date pits

\begin{tabular}{cc}
\hline Composition & $\mathbf{\%}$ \\
\hline Moisture & $5-10$ \\
Protein (N x 6.25) & $5-7$ \\
Oil & $7-10$ \\
Crude fiber & $10-20$ \\
Carbohydrates & $55-65$ \\
Ash & $1-2$ \\
\hline
\end{tabular}

\section{Chemicals}

All chemicals used were of analytical grade.

\section{Ammonia wastewater}

A 100 ppm stock solution of Ammonia was prepared by dissolving suitable amounts of Ammonium chloride in double distilled water and is suitably diluted as per the need. The concentrations used are in the range of 5 to $90 \mathrm{mg} / \mathrm{L}$.

Standard solutions of ammonia ranging from 5 to $75 \mathrm{ppm}$ were made up using distilled water as a solvent. Dilutions of concentrated samples were undertaken in order that the reduced optical density as found from the Spectrophotometer was in the range 0.1 to 0.6 . It was found that more accurate results were obtained in this range. Then by multiplying these reduced optical densities by their dilution factor, the optical density of the original stock solution was obtained. All tests were carried out at room temperature $\left(25 \pm 2^{\circ} \mathrm{C}\right)$ to eliminate any temperature effects, unless otherwise stated. 
Military Technical College

Kobry El-Kobbah,

Cairo, Egypt

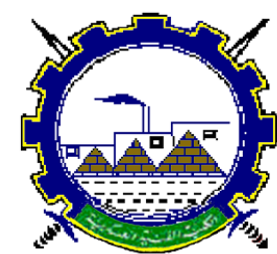

I.C.E.E.2016 $8^{\text {th }}$ International Conference

on

Chemical \& Environmental

Engineering

$19-21$ April 2016

Calibration curve was prepared for different ammonia concentrations using aqueous ammonium chloride solution as synthetic wastewater with ammonia concentrations ranged from 5 to $75 \mathrm{ppm}$. The calibration of ammonia was prepared by recording the absorbance values of ammonia of different concentrations at the maximum wavelength.

The value of $\lambda_{\max }$ was determined as $374 \mathrm{~nm}$ and the absorbance of ammonia in accordance with the Beer-Lambert's law follows a linear relationship with concentration.

\section{Nessler's reagent}

35gm of Potassium Iodide and 4\% Mercuric Chloride were dissolved in $100 \mathrm{ml}$ of double distilled water with constant stirring until a slight red precipitate remains. To this, solution of $\mathrm{NaOH}(120 \mathrm{gms}$ of $\mathrm{NaOH}+250 \mathrm{ml}$ of double distilled water) was added and made up to $1 \mathrm{~L}$ with double distilled water. A little more Mercuric Chloride solution was added until there was a permanent turbidity. The mixture was allowed to stand for one day and decant from the sediment. The solution was kept in stoppered dark colored bottle.

\section{Analytical Techniques}

The residual ammonia concentrations of the samples were measured after the reaction time using a spectrophotometer (SHIMADZU-UV 1601, Model TCC-240A) after the Nessler reagent is added.

\section{Methodology:}

Two series of batch-type experiments were carried out. Adsorption equilibrium was derived from small-scale batch experiments and kinetic data were derived from larger scale contact time experiments. Kinetics of adsorption was carried out using agitated batch adsorber.

\section{Equilibrium Experiments}

Date pits in contact with $25 \mathrm{ml}$ of ammonia solutions which were prepared in distilled water at concentrations ranging from 5 to $75 \mathrm{mg} / \mathrm{L}$ was used to investigate the equilibrium uptake of dye ions at $303 \mathrm{~K}$ with a sorbent mass of $0.5 \mathrm{~g}$. The solution with the adsorbent was mechanically shaken at $200 \mathrm{rpm}$ and $303 \mathrm{~K}$ for 240 minutes. Thereafter, the samples were analysed for the ammonia remaining in the solution. The results founded that equilibrium was established within $3 \mathrm{hr}$; however, all equilibrium experiments were allowed to run for $4 \mathrm{hr}$ to ensure uniformity.

Adsorption isotherms were determined by using the following procedure. The experiments were carried out at different temperatures of 25,40 and $60 \pm 2{ }^{\circ} \mathrm{C}$. The experiments were 
Military Technical College

Kobry El-Kobbah,

Cairo, Egypt

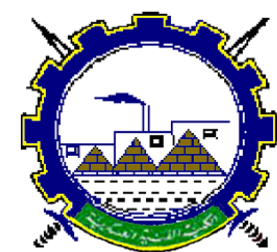

I.C.E.E.2016 $8^{\text {th }}$ International Conference

on

Chemical \& Environmental

Engineering

$19-21$ April 2016

carried out with shaker containing water bath with electrical heater and thermometer. The bottles were shaken submerged in water bath, controlled at $\pm 2{ }^{\circ} \mathrm{C}$. The experiments were started when the temperature of the solution reached to the required value. After $240 \mathrm{~min}$. samples were taken and remaining ammonia was analyzed.

\section{Isotherm experiment}

In this study, the adsorption data were analyzed using Langmuir and Freundlich adsorption isotherm models to describe the sorption equilibrium.

The Langmuir isotherm is based on the assumption that maximum adsorption corresponds to a saturated monolayer of solute molecules on the adsorbent surface. The linear form of the Langmuir isotherm is represented as follows:

$$
\frac{C_{e}}{q_{e}}=\frac{1}{K_{L} a_{L}}+\frac{1}{K_{L}} C_{e}
$$

Where $\mathrm{C}_{\mathrm{e}}$ is the equilibrium dye concentration $\left(\mathrm{mg} \mathrm{L}^{-1}\right), \mathrm{q}_{\mathrm{e}}$ is the mass of dye adsorbed per unit mass of adsorbent $\left(\mathrm{mg} \mathrm{g}^{-1}\right), \mathrm{K}_{\mathrm{L}}$ and $\mathrm{a}_{\mathrm{L}}$ are the Langmuir constants related to the adsorption capacity and rate of adsorption, respectively.

The Freundlich isotherm model is applicable to a highly heterogeneous surface:

$$
\ln \left(q_{e}\right)=\ln K_{F}+\frac{1}{n} \ln C_{e}
$$

Where $K_{F}$ relates to the adsorption capacity of the adsorbent and $n$ is a measure of the adsorption intensity. The magnitude of the coefficient, $1 / \mathrm{n}$, gives an indication of how favourable the adsorption is; values of $\mathrm{n}>1$ represent favourable adsorption conditions [22].

\section{Kinetic Study}

The study of the adsorption kinetics describes the resistance to solute transfer from the solution to the boundary layer at the solid-liquid interface to the pore water and then to the solid. It is well known that the following steps mainly control adsorption kinetics:

1. Solute molecules transfer from the solution to the boundary film; 2. Solute molecules transfer from the film to the surface of the sorbent (external diffusion); 3. Diffusion from the surface to intra-particle sites and 4. Interaction of solute molecules with the available sites on the internal surface [23]. The evolution of the adsorption process can be followed by measuring the number of particles adsorbed per unit time. Many kinetic models have been proposed for the adsorption of solutes on solids. 
Military Technical College

Kobry El-Kobbah,

Cairo, Egypt

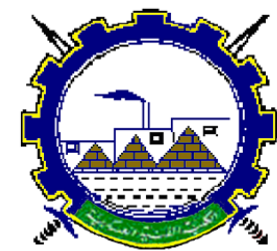

I.C.E.E.2016 $8^{\text {th }}$ International Conference

on

Chemical \& Environmental

Engineering

19 - 21 April 2016

\section{Results and discussions}

\subsection{Preliminary Adsorption Studies}

\subsubsection{Effect of Contact time}

The contact time studies were carried out to understand the trend of ammonia adsorption over a period of time at $363 \mathrm{mg} / \mathrm{L}$ ammonia concentration by taking fixed amount $(0.1 \mathrm{~g})$ of date stone. Figure 2 showed the amount of the ammonia adsorbed per unit mass of adsorbent $\left(\mathrm{q}_{\mathrm{e}}\right)$ increased with increasing time before reaching a plateau. The equilibrium is achieved after a contact time of approximately 180 minutes. However, to allow some factor of safety, all the experiments were carried out with 250 minutes of contact time. There was no noticeable improvement in the removal when the contact time was prolonged. The initial high rate of ammonia uptake may be attributed to the existence of the date pits surface; however, the number of available adsorption sites decreased as the concentration of ammonia adsorbed increased. Moreover, ammonia removal curves are single smooth and continuous indicating the formation of monolayer coverage on the surface of adsorbent. This observation was also reported by Mittal et al., (2013) for Eosin dye removal onto De-oiled waste Soya adsorbent [24]. The maximum ammonia removal of ammonia reached in this study to $37 \%$ at ambient temperature, which is in accordance with Ghauri et al., [25] which reached to $40 \%$ at $60^{\circ} \mathrm{C}$.

\subsubsection{Effect of Temperature}

The effect of temperature on the sorption of the ammonia/date pits system was studied at 25 , 40 and $60{ }^{\circ} \mathrm{C}$ and the results were displayed in Fig. 3. The results revealed that the sorption capacity decreased with temperature increase. This decrease in sorption capacity with temperature is due to the enhancement of the desorption step in the sorption mechanism indicating that the process is exothermic. It is known that decreasing sorption capacity with increasing temperature is mainly due to the weakening of sorptive forces between the active sites on the date pits and ammonia species, and also between adjacent ammonia molecules on the sorbed phase. For a conventional mechanism of physic-sorption system, increase in temperature usually increases the rate of approach to equilibrium, but decreases the equilibrium capacity [24-26].

\subsection{Adsorption Isotherms}

The adsorption isotherm is the relationship between the amount of a substance adsorbed and its concentration in the equilibrium solution at a constant temperature. The function isotherm models, for example Langmuir and Freundlich, to the adsorption study was assessed by comparing the correlation coefficients, $\mathrm{R}^{2}$ values. 
Military Technical College

Kobry El-Kobbah,

Cairo, Egypt

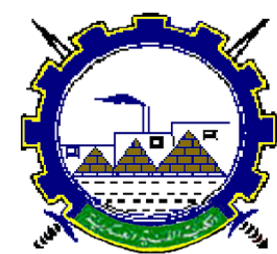

I.C.E.E.2016 $8^{\text {th }}$ International Conference

on

Chemical \& Environmental

Engineering

$19-21$ April 2016

As shown in Fig. 4a Langmuir isotherm was chosen to show the maximum adsorption capacity. The values of maximum adsorption capacity can be obtained from the slope of the plot of Ce/qe versus Ce. The correlation coefficient of the Langmuir isotherm, $\mathrm{R}^{2}$ is 0.99 . The essential characteristics of the Langmuir isotherm can be expressed in terms of a dimensionless constant.

In addition, Freundlich isotherm is applied by plotting of $\ln$ qe versus $\ln C e$ in Fig. $4 \mathrm{~b}$ shows a straight line with a correlation coefficient of 0.92 . The constants $\mathrm{K}_{F}$ and $1 / \mathrm{n}$ were determined from the plot. A high regression correlation coefficient was shown by the Langmuir model, and indicates that the Langmuir model was suitable for describing the sorption equilibrium of ammonia by date pits adsorbent. Similar results were reported for dye adsorption on powder and flakes chitosan [27].

The results obtained showed that the Langmuir equation could be applied to the adsorption of ammonia onto date stone over the entire solute concentration range adopted in experimental studies. On the other hand, the Langmuir equation better fitted the experimental data since the average percent deviation for the Langmuir model is lower than the other model. This conclusion was supported by comparing correlation coefficients generated by linear plots performed on the Langmuir and the Freundlich equation data. These coefficients are a measure of the conformity of the data to a linear trend, a value of one would indicate a perfect fit. The correlation coefficients obtained from the Langmuir plots were higher overall (i.e closer to 1) than those obtained from the Freundlich plots Fig. (5).

\subsection{Adsorption Kinetics}

The study of the adsorption kinetics describes the resistance to solute transfer from the solution to the boundary layer at the solid-liquid interface to the pore water and then to the solid.

It is well known that adsorption kinetics is mainly controlled by the following steps:

1. Solute molecules transfer from the solution to the boundary film; 2. Solute molecules transfer from the film to the surface of the sorbent (external diffusion); 3. Diffusion from the surface to intra-particle sites and 4. Interaction of solute molecules with the available sites on the internal surface [28].

The evolution of the adsorption process can be followed by measuring the number of particles adsorbed per unit time. Many kinetic models have been proposed for the adsorption of solutes on solids. They include, amongst others, the pseudo-first order kinetic model and the pseudosecond order model. 
Military Technical College

Kobry El-Kobbah,

Cairo, Egypt

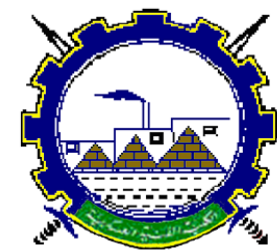

I.C.E.E.2016 $8^{\text {th }}$ International Conference

on

Chemical \& Environmental

Engineering

$19-21$ April 2016

\subsubsection{Effect of system variables on adsorption of ammonia}

Kinetic study was conducted by varying the system variables of an agitated-batch adsorber, these variables are: the agitation speed, the initial ammonia concentration of ammonium chloride solution and the mass of adsorbent (Date pits).

Fig. 6-8 represent the effect of agitation speed, the initial concentration and the mass of adsorbent on adsorption of ammonia by plotting $\mathrm{qe}(\mathrm{mg} / \mathrm{g})$ against the contact time (min) which was 240 minutes.

\subsubsection{Effect of agitation speed}

The agitation speed is an important parameter in sorption phenomena, which has a serious action on the distribution of the solute in the bulk solution and the formation of the external boundary film. The effect of agitation on the uptake of ammonia was studied at different agitation speeds (100-800 rpm). From Fig. 6, it can be observed that agitation speed significantly affects the adsorption of ammonia, thus confirming that the influence of external diffusion on the sorption kinetic control plays a significant role.

The percent of dye adsorbed was found to increase with increased in agitation speed from 100 $\mathrm{rpm}$ to $800 \mathrm{rpm}$, thus confirming that the influence of external diffusion on the sorption kinetic control plays a significant role. With increasing the agitation speed, the rate of diffusion of dye molecules from bulk liquid to the liquid boundary layer surrounding the particle becomes higher because of an enhancement of turbulence and a decrease of thickness of the liquid boundary layer [29].

\subsubsection{Effect of initial concentration}

The adsorption behaviours of ammonia on date pits were examined in concentrations ranging from 30 to $95 \mathrm{mg} / \mathrm{L}$, at a fixed sorbent of $1.7 \mathrm{~g}$. The experimental results (in Fig. 7) reveal that sorption was more favourable for the lower initial ammonia concentrations than the higher ones. This finding is due to the increase in availability of surface active sites resulting from the increased adsorbent/adsorbate ratio [30]. This result in accordance with Gupta $t$ al., [31] for azo dye removal using $\mathrm{TiO}_{2}$, nevertheless, Mittal and Gupta [32] recorded that the sorption of azo dye Eriochrome Black T onto bottom ash and de-oiled soya is increased with increasing the concentration uptake.

\subsubsection{Effect of adsorbent mass}

The effect of the sorption capacity on the removal of ammonia was examined by varying the sorbent masses of $0.5,1.0,1.7,2.0$ and $2.5 \mathrm{~g}$ by fixing other conditions. It is apparent from (Fig. 8) that by increasing the dose of the date pits, the number of sorption sites available for sorbent interaction is increased, thereby resulting in the increased percentage dye removal 
Military Technical College

Kobry El-Kobbah,

Cairo, Egypt

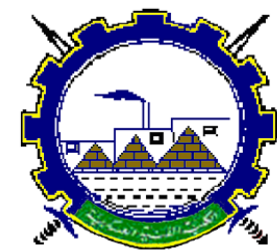

I.C.E.E.2016 $8^{\text {th }}$ International Conference

on

Chemical \& Environmental

Engineering

$19-21$ April 2016

from the solution. The decrease in sorbent capacity may be attributed to: (a) the increase in sorbent dose at constant ammonia concentration and volume leads to unsaturation of sorption sites [33]; (b) particulate interaction such as aggregation resulting from high sorbent dose. Such aggregation would result in a decrease in total surface area of the sorbent and an increase in diffusional path length [33]. Those results of increasing the sorption capacity with increasing the sorbent amount are in agreement with the previous findings of Mittal et al. [24].

\subsubsection{Comparison between first and second kinetics orders for ammonia adsorption on date pits:}

Examination of the results presented in Table 2 shows that the adsorption data fitted best to the pseudo-second order rate equation since the correlation coefficient is close to one and higher than that for the first order.

Table 2 Comparison of first and second order reaction kinetic constants for ammonia adsorption on the date pits

\begin{tabular}{|c|c|c|c|c|c|c|}
\hline \multicolumn{3}{|c|}{ Adsorption condition } & \multicolumn{2}{|c|}{$\begin{array}{l}\text { Pseudo-first order } \\
\text { kinetic model }\end{array}$} & \multicolumn{2}{|c|}{$\begin{array}{l}\text { Pseudo-second order } \\
\text { kinetic model }\end{array}$} \\
\hline $\begin{array}{l}\text { Agitation } \\
\text { speed } \\
(\mathrm{rpm})\end{array}$ & $\begin{array}{l}\text { Initial } \\
\text { concentration } \\
\text { of the ammonia } \\
(\mathrm{mg} / \mathrm{L})\end{array}$ & $\begin{array}{l}\text { Mass } \\
\text { adsorbent } \\
(\mathrm{g})\end{array}$ & $\begin{array}{c}\mathrm{K}_{1} \\
\left(\mathrm{~min}^{-1}\right)\end{array}$ & $\mathrm{R}^{2}$ & $\begin{array}{l}\mathrm{K}_{2}\left(* 10^{3}\right), \\
\left(\mathrm{g} \cdot \mathrm{mg}^{-1} \mathrm{~min}^{-1}\right)\end{array}$ & $\mathrm{R}^{2}$ \\
\hline 100 & 95 & 1.7 & 0.009200 & 0.990 & 0.000853 & 0.940 \\
\hline 300 & 95 & 1.7 & 0.016121 & 0.975 & 0.001435 & 0.976 \\
\hline 400 & 95 & 1.7 & 0.013818 & 0.0997 & 0.001538 & 0.976 \\
\hline 500 & 95 & 1.7 & 0.013818 & 0.957 & 0.001516 & 0.979 \\
\hline 600 & 95 & 1.7 & 0.020727 & 0.999 & 0.002324 & 0.977 \\
\hline 800 & 95 & 1.7 & 0.018420 & 0.999 & 0.002272 & 0.968 \\
\hline 500 & 30 & 1.7 & 0.018424 & 0.978 & 0.002792 & 0.990 \\
\hline 500 & 45 & 1.7 & 0.016121 & 0.999 & 0.004058 & 0.997 \\
\hline 500 & 60 & 1.7 & 0.018424 & 0.966 & 0.002121 & 0.995 \\
\hline 500 & 75 & 1.7 & 0.018424 & 0.949 & 0.001519 & 0.997 \\
\hline 500 & 95 & 0.5 & 0.027636 & 0.961 & 0.000720 & 0.998 \\
\hline 500 & 95 & 1.0 & 0.018424 & 0.999 & 0.000509 & 0.997 \\
\hline 500 & 95 & 2.0 & 0.018424 & 0.971 & 0.0014170 & 0.997 \\
\hline 500 & 95 & 2.5 & 0.020727 & 0.978 & 0.0015169 & 0.999 \\
\hline
\end{tabular}

$\mathrm{R}^{2}$ : Correlation factor; $\mathrm{K}_{1}$ and $\mathrm{K}_{2}$ are first and second reaction kinetics, respectively 
Military Technical College

Kobry El-Kobbah,

Cairo, Egypt

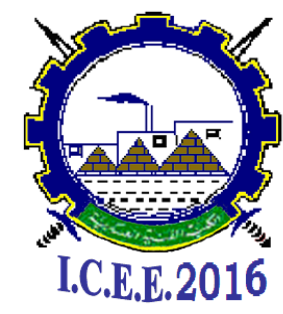

$8^{\text {th }}$ International Conference

on

Chemical \& Environmental

Engineering

$19-21$ April 2016

Thus, this applicable to describe the adsorption process of the dye onto bare palm, based on assumption that the rate-limiting step maybe chemical sorption involving valence forces through sharing or exchange of electrons between sorbent and sorbate, provide the best correlation of data Similar results were reported for the adsorption of oil by powder and flake chitosan Ahmad et al., [26].

\section{Conclusion}

The present study demonstrated that date pits, which are abundantly available in Egypt, is an efficient sorbent for the removal of ammonia in water and it may be an alternative to more costly adsorbents such as activated carbon. The batch studies clearly suggest that date pits activated carbon exhibits almost reached to around 50\% when the temperature is increased. Equilibrium data fitted well with the Langmuir model, which suggests coverage of ammonia molecules on the surface of the date pits. In addition, the reaction follows pseudo-first-order kinetics model. The most important features of this process making it applicable to the treatment of contaminated aqueous effluents are: the process takes place at ambient temperature and without over pressure and the catalyst is cheap and innocuous.

\section{References}

[1] H.A. El Gammal and H.S. El Shazely, Water quality management senarios in Rosetta River Nile branch, Twelfth International Water Technology Conference, IWTC12, Alexandria, Egypt, 2008, 901-912.

[2] D.K. Lee, Mechanism and Kinetics of the Catalytic Oxidation of Aqueous Ammonia to Molecular Nitrogen, Environ. Sci. Technol. 37 (2003) 5745-5749.

[3] K. Prameela Rani and K. Ravindhranath, New Bio-Sorbents in the Control of Ammonia Pollution in Waste Waters, Asian J. Research Chem., (2014), 7(5).

[4] US. Environmental Protection Agency, Quality Criteria for Water. Washington, DC. 1976, 16.

[5] R. E. Luebs, A. E. Laag, Calif. Agric., 27 (1973) 10.

[6] Hazardous Substances Data Bank: Ammonium Chloride, Bethesda, M. D., National Library of Medicine 1990

[7] AWWA, Water Quality and Treatment, McGraw Hill Co., New York, 1990.

[8] M. A. Gaspard, Neveu, G. Martin, Water Res., 17 (1983) 279.

[9] I. Ozturk, M. Altinbas, I. Koyuncu, O. Arikan and C.G. Yangin, Advanced physicochemical treatment experiences on young municipal landfill leachates, Waste Manage. 23 (2003) 1446.

[10] L.D. Palma, P. Ferrantelli, C. Merli and E. Petrucci, Treatment of industrial landfill leachate by means of evaporation and reverse osmosis, Waste Manage. 22 (2002) 951955. 
Military Technical College

Kobry El-Kobbah,

Cairo, Egypt

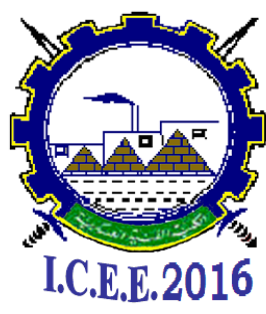

$8^{\text {th }}$ International Conference

on

Chemical \& Environmental

Engineering

$19-21$ April 2016

[11] M. Altinbas, C. Yangin and I. Ozturk, Struvite precipitation from anaerobically treated municipal and landfill wastewaters, Water Sci. Technol. 46 (2002) 271-278.

[12] L. Li, X.Fang, D. Zhang and Y. Huang, The Adsorption and Oxidation of Ammonia in Granular Activated Carbon Packed Three-Dimensional Electrode Reactor, Int. J. Electrochem. Sci., 10 (2015) 4083 - 4089

[13] S.M. Anisuzzaman, C. G. Joseph, Y.H. Taufiq-Yap and D. Krishnaiah, V.V. Ta, Modification of commercial activated carbon for the removal of 2,4-dichlorophenol from simulated wastewater, J. King Saud Uni.-Sci., 27(4), (2015), 318-330.

[14] K. Prameela Rani and K. Ravindhranath, New Bio-Sorbents in the Control of Ammonia Pollution in Waste Waters, Asian J. Research Chem. (2014) 7(5).

[15] M. Zendehzaban a, Y. Shavisib, S. Kakehazarb, M.A. Khadivib, Sh.Sharifnia, Removal of Ammonia from Petrochemical Wastewater by Photocatalytic Process, oceedings of the 4th International Conference on Nanostructures (ICNS4) 12-14 March, 2012, Kish Island, I.R. Iran

[16] V. Parimala, K.K. Krishnani, B.P.Gupta, R. Ragunatha, S.M. and P. Aillai. Ravichandran, removal of ammonia and nitrite from environment, Contam. Toxicol, 78 (2007) 288-293.

[17] S. Korner , J.E. Vermaat and S. Veenstra, The capacity of duck weed to treat wastewater: ecological considerations for a sound design, J. Environ. Qual. 32 (2003) 1583-90.

[18] K.K. Krishnani , K.O. Joseph, B.P. Gupta, M. Muralidhar and A. Nagavel. Studies on the use of neem products for removal of ammonia from brackish. J. Environ Sci Health A , 37 (2002) 893-904.

[19] K.K. Krishnani , B.P Gupta, K.O. Joseph, M. Muralidhar, C. Sarda, A Nagavel and V. Parimala, removal of ammonia from polluted water using new biosorbent, Bull Environ Cntam Toxicol , 71 (2003) 196.

[20] M. Belhachemi and F. Addoun, Adsorption properties of modified date pits activated carbons, Proceedings of the Global conference on Flobal Warming, Lisbon, Portugal, 2011, 11-14.

[21] Y. A. Alhamed, Activated Carbon from Dates' Stone by $\mathrm{ZnCl}_{2}$ Activation, JKAU: Eng. Sci., 17 (2006) $75-100$.

[22] Ho Y. and G. McKay, Sorption of dye from aqueous solution by peat. Chem. Eng. J., 70 (1998) 115-124.

[23] E. Demirbas, M. Kobya, E. Senturk, and T. Ozkan, Adsorption Kinetics for the Removal of Chromium(VI) from Aqueous Solutions on the Activated Carbons prepared from Agricultural Wastes, Water SA, 30 (2007) 533-539.

[24] A. Mittal, D., Jhare, and J. Mittal, "Adsorption of hazardous dye Eosin Yellow from aqueous solution onto waste material De-oiled Soya: Isotherm, kinetics and bulk removal,”. J. Molecular Liquids, 179 (2013) 133-140.

[25] Y. Ho, W. Chiu, and C. Wang, Regression analysis for the sorption isotherms of basic dyes on sugarcane dust, Bioresource Technol., 96: 11 (2005) 1285-1291. 
Military Technical College

Kobry El-Kobbah,

Cairo, Egypt

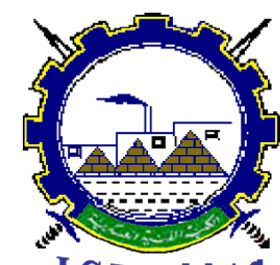

I.C.E.E.2016 $8^{\text {th }}$ International Conference

on

Chemical \& Environmental

Engineering

$19-21$ April 2016

[26] A. Ahmad, S. Bhatia, N. Ibrahim, and S. Sumathi. Adsorption of residual oil from palm oil mill effluent using rubber powder, Brazilian J. Chem. Eng., 22 (2005) 371-379.

[27] M. Ghauri, Muhammad,T.Abbas, M. Khurram and K, Shehzad, Desorption studies for the removal of ammnia by thermally activated carbon, Sci.Int.(Lahore), 24(4), (2012) 411-414.

[28] E. Demirbas, M. Kobya, E. Senturk, and T. Ozkan, Adsorption Kinetics for the Removal of Chromium(VI) from Aqueous Solutions on the Activated Carbons prepared from Agricultural Wastes, Water SA, 30 (2007) 533-539.

[29] Mall, I.D., V.C. Srivastava, N.K. Agarwa and I.M. Mish, Adsorptive Removal of Malachite Green Dye from Aqueous Solution by Bagasse Fly Ash and Activated Carbon- Kinetic Study and Equilibrium Isotherm Analyses. Colloids Surf. A. 264 (2007) 17-28.

[30] S. Patil, S. Renukdas, and N. Patel, Removal of methylene blue, a basic dye from aqueous solutions by adsorption using teak tree ( Tectona grandis) bark powder, Intern. J. Environ. Sci., 1: 5 (2011) 711-726.

[31] V. Gupta, R. Jain, A. Mittal, T. Saleh, A. Nayak, S. Agarwal, and S. Sikarwar, Photocatalytic degradation of toxic dye amaranth on $\mathrm{TiO}_{2} / \mathrm{UV}$ in aqueous suspensions. Mater. Sci. Eng., 32, (2012) 12-17.

[32] A. Mittal, and V. Gupta, Adsorptive removal and recovery of the azo dye Eriochrome Black T, Toxil. Environ. Chem., 92 (2010) 1813-1823.

[33] A. Shukla Y. Zhang, P. Dubey, J. Margrave, and S. Shukla, The role of sawdust in the removal of unwanted materials from water, J. Hazard. Mater., 95 (2002) 137-52.

[34] A. Mittal, V. Thakur, J. Mittal, and H. Vardhan.. Process development for the removal of hazardous anionic azo dye Congo red from wastewater by using hen feather as potential adsorbent," Desalination Water Treat. 1-11 (2014) 227-237. 
Military Technical College Kobry El-Kobbah, Cairo, Egypt

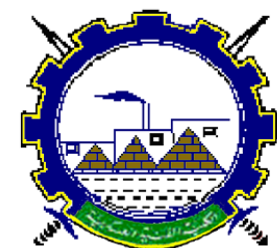

I.C.E.E.2016 $8^{\text {th }}$ International Conference

on

Chemical \& Environmental

Engineering

19-21 April 2016

Fig. 1 Image of the raw date pits

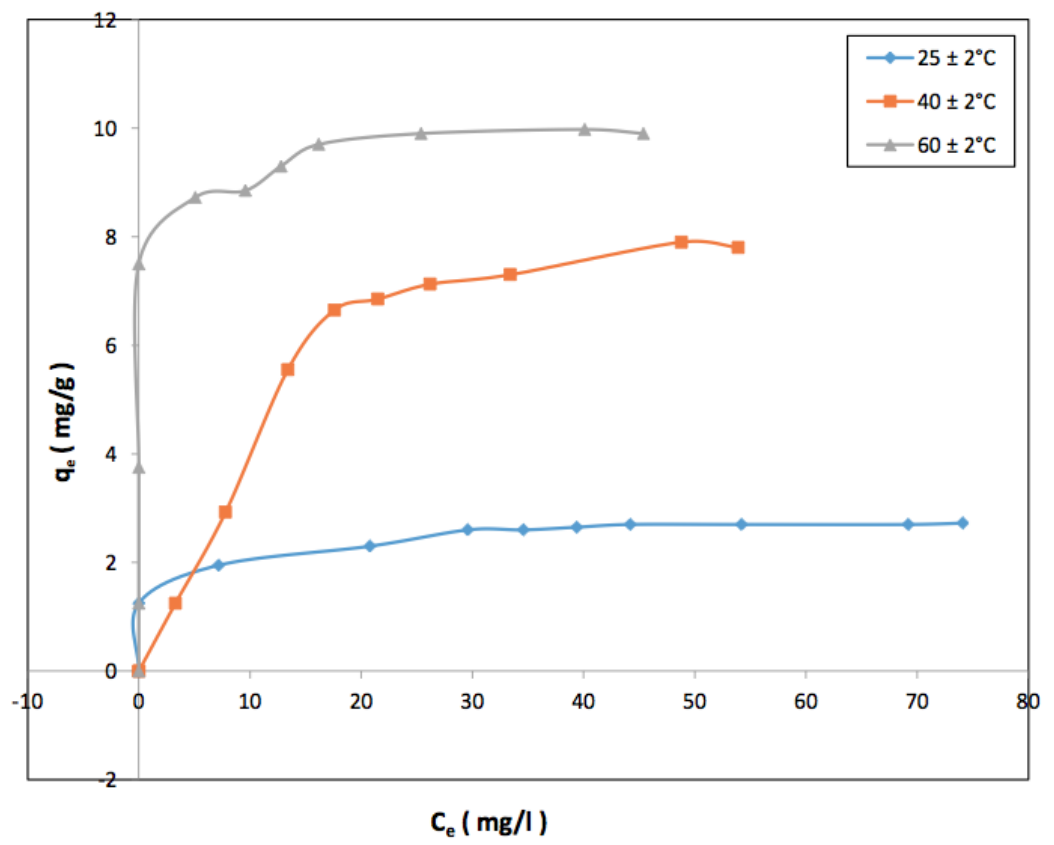

Fig. 3 Adsorption equilibrium of Ammonia onto Date Stone at different Temperatures 
Military Technical College

Kobry El-Kobbah,

Cairo, Egypt

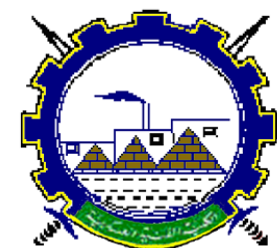

I.C.E.E.2016 $8^{\text {th }}$ International Conference

on

Chemical \& Environmental

Engineering

$19-21$ April 2016

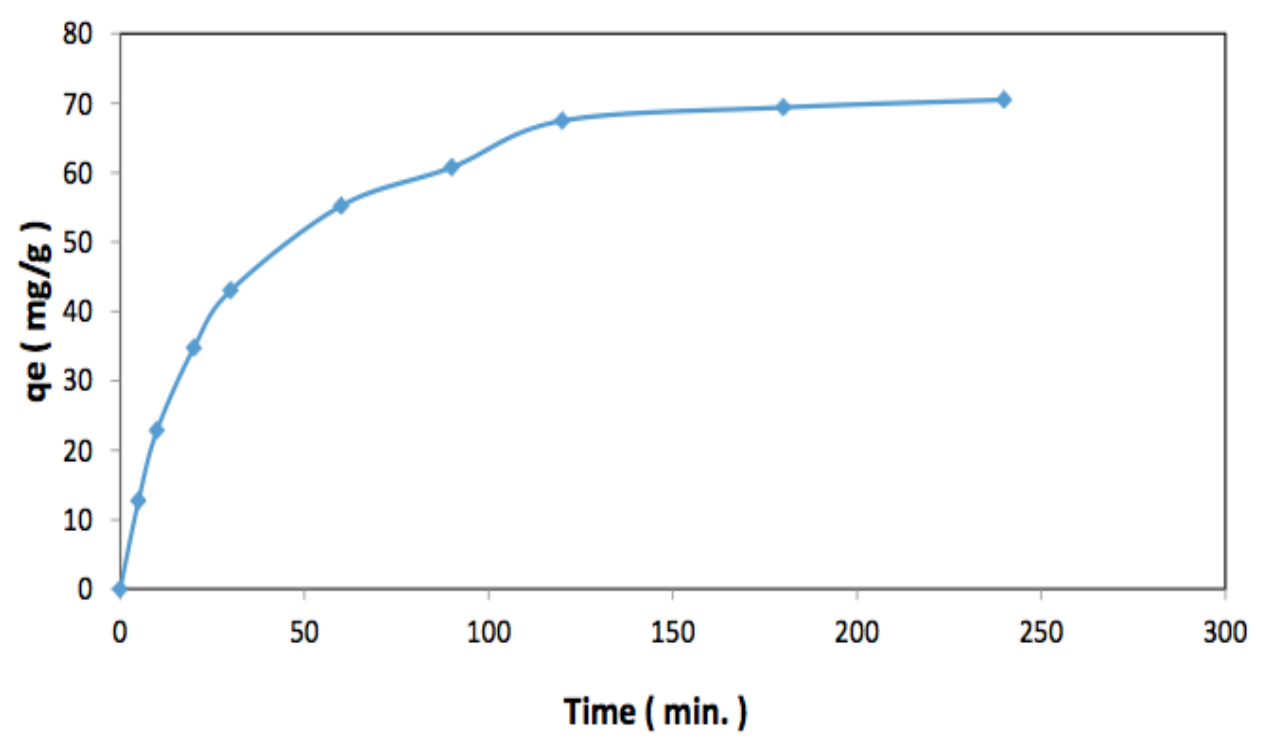

Fig. 2 Equilibrium-time for adsorption of Ammonia onto Date Stone at $25 \pm 2^{\circ} \mathrm{C}$

(a)

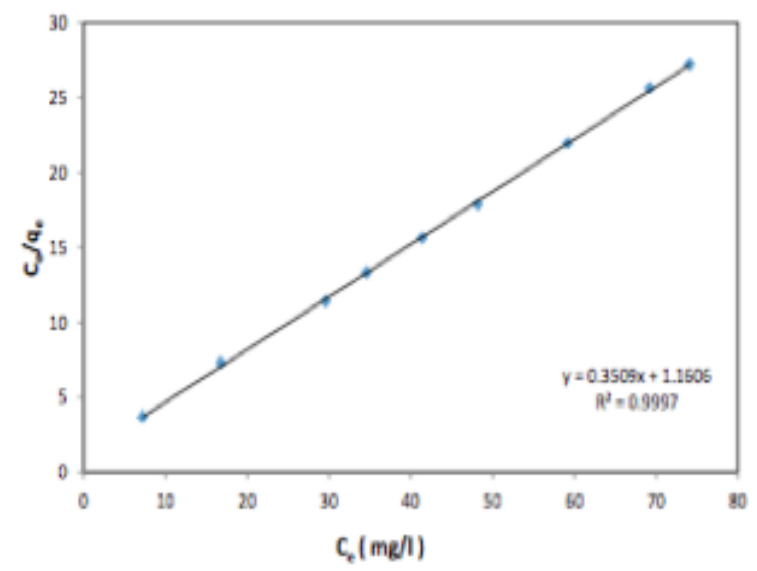

(b)

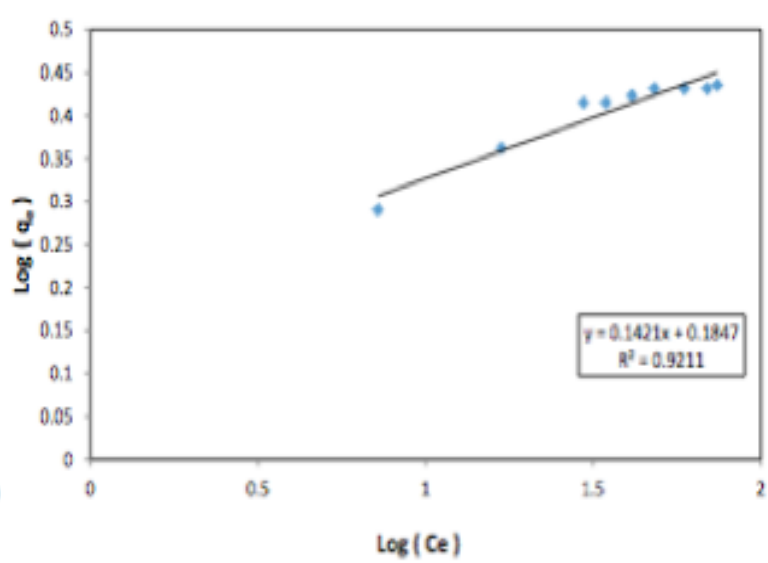

Fig.4 (a) Langmuir; (b) Freundlich isotherms for ammonia adsorption onto Date Stone at $25^{\circ} \mathrm{C}$ 
Military Technical College Kobry El-Kobbah, Cairo, Egypt
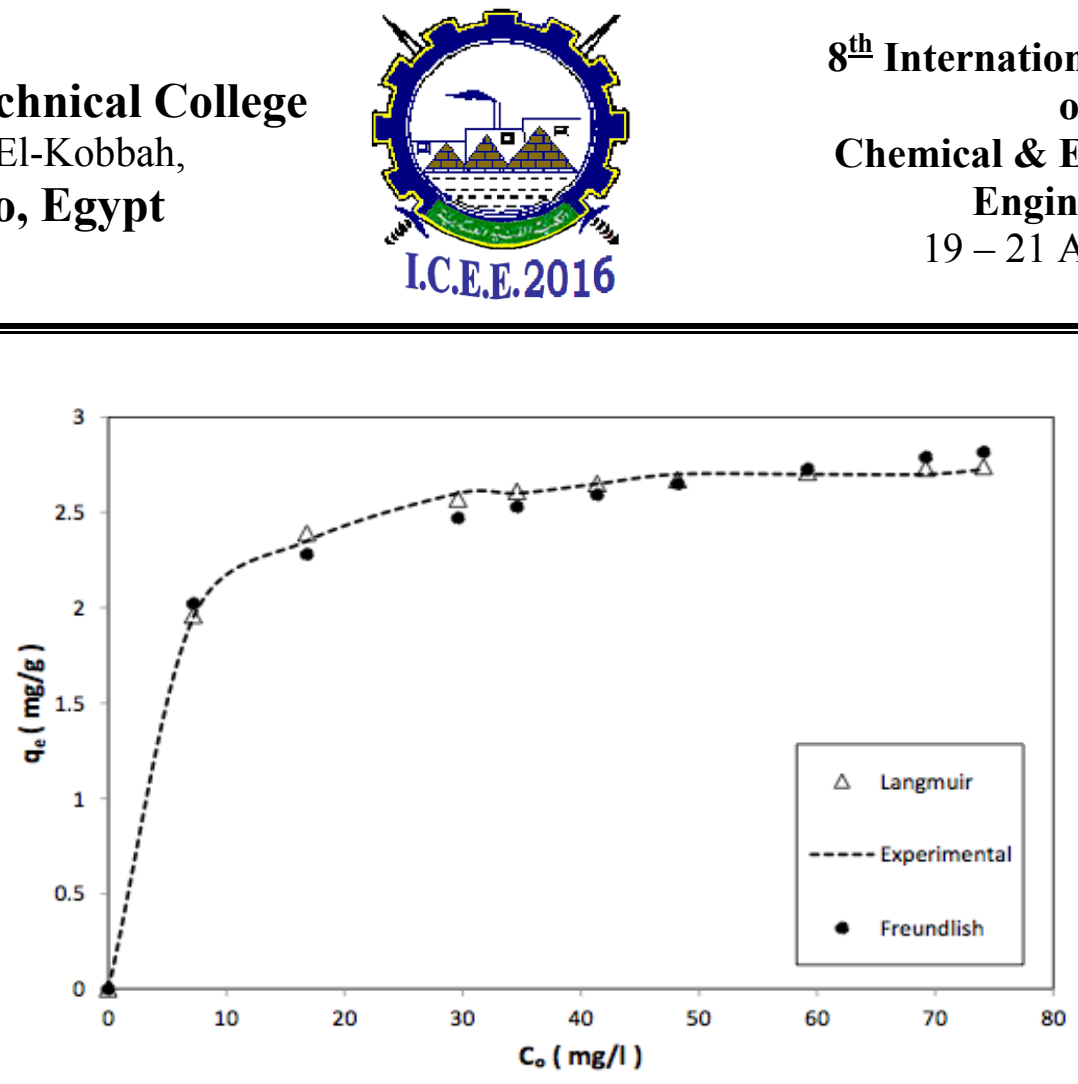

Fig. 5 Comparison between experimental and theoritical isotherms for the adsoaption of Ammonia onto Date Pits

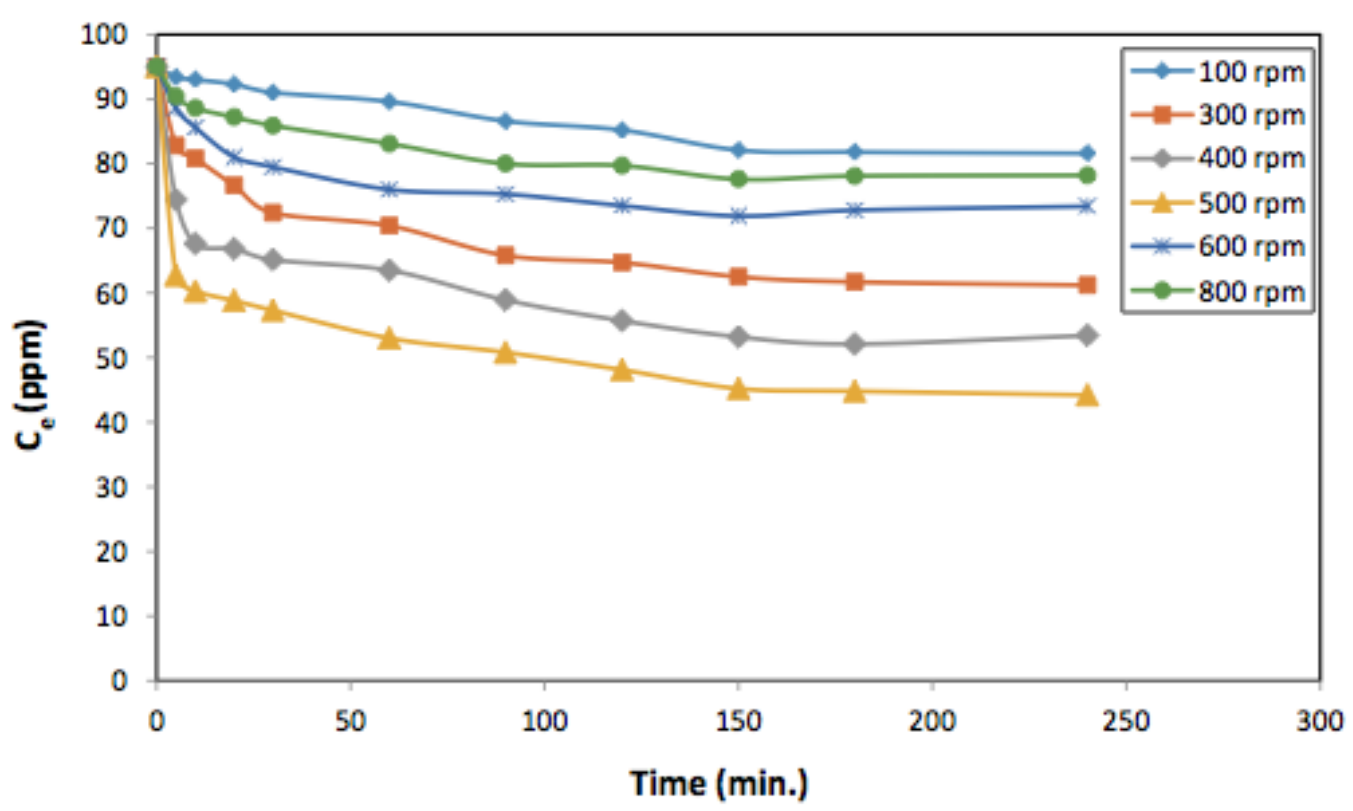

Fig. 6 Effect of agitation speed on adsorption of ammonia onto Date Pits $[\mathrm{Co}=95 \mathrm{mg} / \mathrm{L}$, $\left.\mathrm{m}=1.7 \mathrm{~g}, \mathrm{~V}=1.7 \mathrm{~L}, \mathrm{~T}=25 \pm 2^{\circ} \mathrm{C}\right]$ 
Military Technical College

Kobry El-Kobbah,

Cairo, Egypt

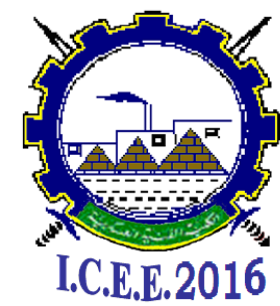

$8^{\text {th }}$ International Conference

on

Chemical \& Environmental

Engineering

19 - 21 April 2016

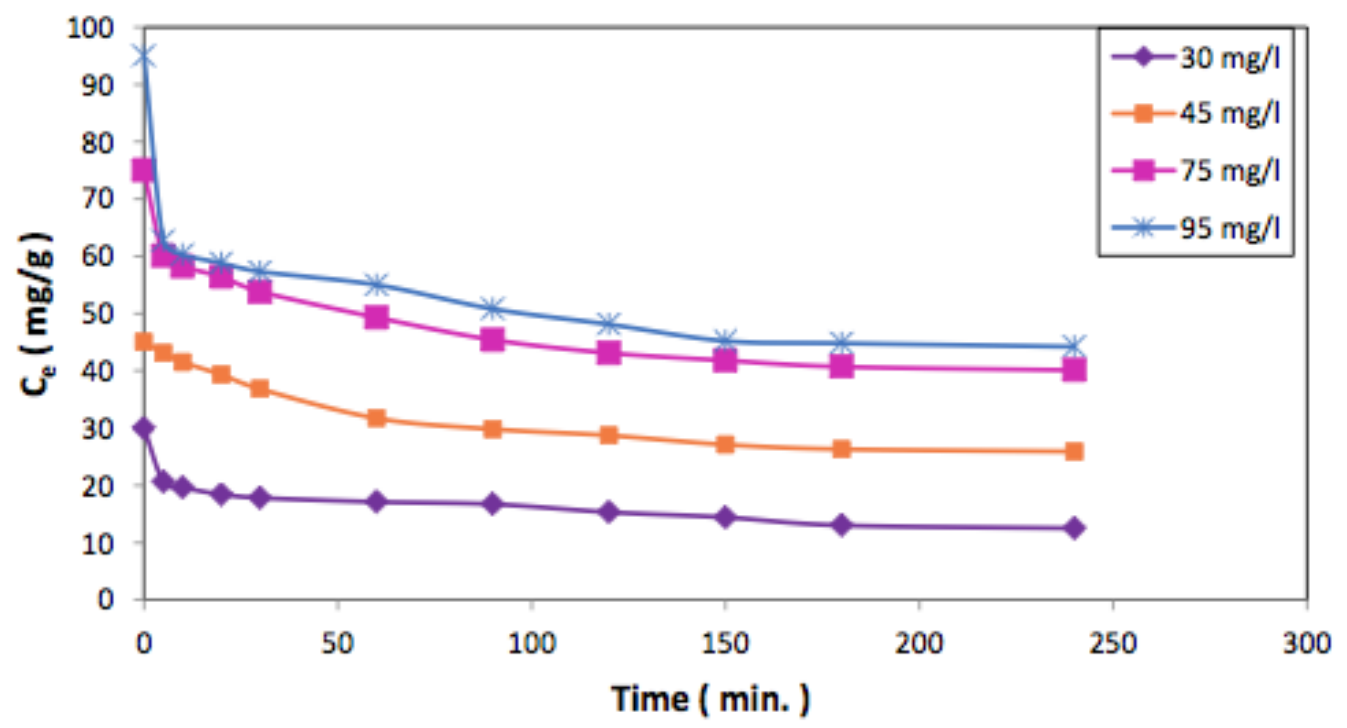

Fig. 7 Effect of initial concentration on adsorption of ammonia onto Date Stone $\left[\mathrm{rpm}=500, \mathrm{~m}=1.7 \mathrm{gm}, \mathrm{Vol}=1.7 \mathrm{~L}, \mathrm{~T}=25 \pm 2^{\circ} \mathrm{C}\right]$

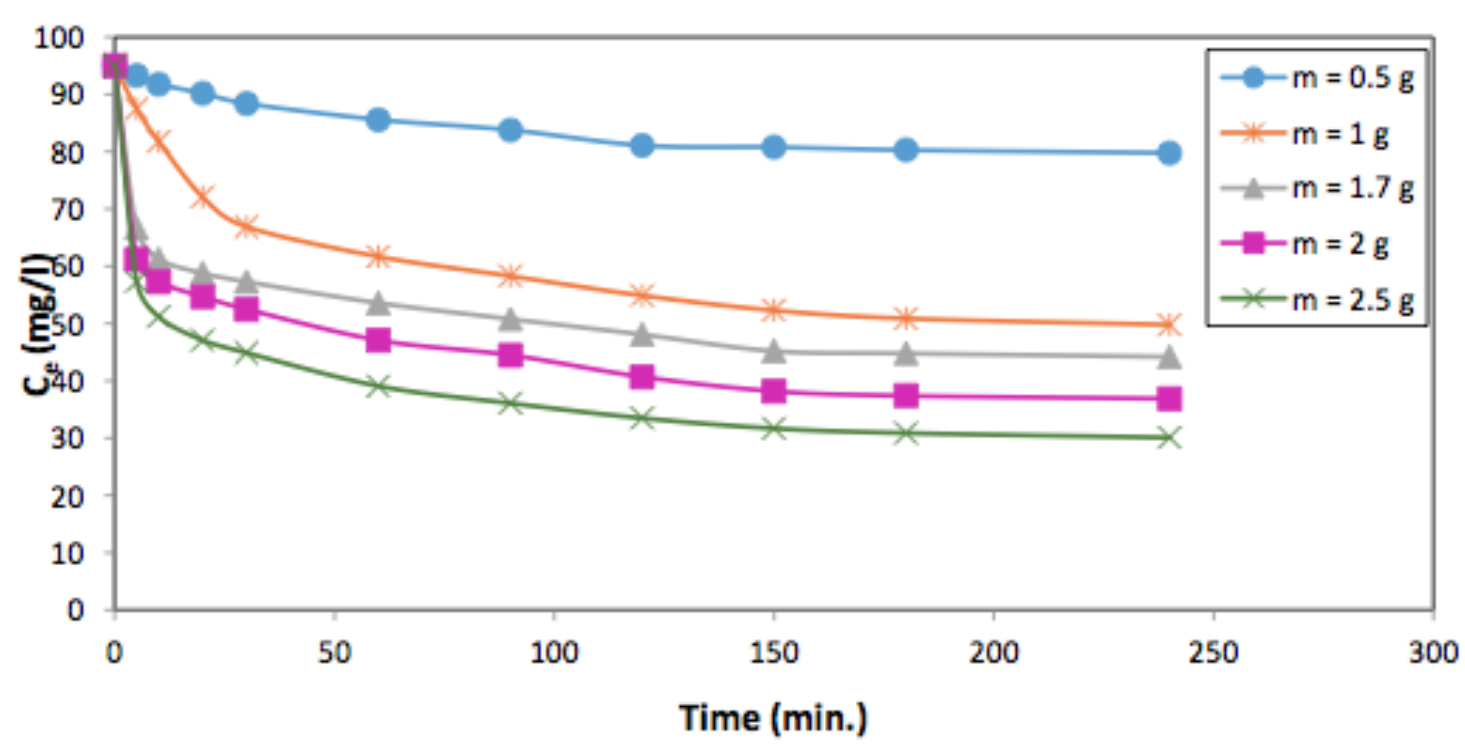

Fig. 8 Effect of adsorbent mass on adsorption of ammonia onto Date Stone $\quad[\mathrm{rpm}=\mathbf{5 0 0}$, $\left.\mathrm{Co}=95 \mathrm{mg} / \mathrm{l}, \mathrm{V}=1.7 \mathrm{~L}, \mathrm{~T}=25 \pm 2^{\circ} \mathrm{C}\right]$ 